岡山医誌（1990）102，1345～1350

\title{
クロルデンのラット肝ミトコンドリアの 呼吸活性に対する作用
}

\author{
岡山大学医学部公衆衛生学講座（指導：緒方正名教授）
}

出石文男

(平成 2 年 9 月 4 日受稿)

\begin{abstract}
Key words: Chlordane, Mitochondria, Oxidative phosphorylation, Electron transport system
\end{abstract}

緒

\section{言}

クロルデンは有機塩素系殺虫戍であり，我が 国では白蟻駆除剤として広く使用されてきた1). その使用量は年々増加の一途をたどってきたが， 1986年 9 月には化学物質番查規制法により使用 禁止になった。白螦防除処理家屋におけるクロ ルデン㴗度の調査結果によれば, 移住空間のみ ならず，噴雺作業者の血液中にもクロルデンが 検出されている2.3. . また, 河川, 湾の泥質, 魚 類への蓄䅡の報告4,5,6,7)があり授乳婦の母乳への クロルデンの移行も報告されている ${ }^{8,99}$. 一方, ラットを用いた暴露実験によりクロルデンの成 分およびそれらの代謝物が長期にわたり脂助組 織, 肝藏等に蓄積することが明らかにされてい $る^{10)}$.クロルデンの動物実験による毒性について は、ラットにおける中枢神経系の刺激, 胃潰瘍, 肝肥大等の発現 ${ }^{11)}$, マウスに扔引る胎児数の減少 と発育低下 ${ }^{12}$, 肝癌の多発など多くの報告があ $3^{13)}$. 芳香族八ロゲン化合物として塩化ベンゼン の肝毒性についてはいくつか報告されている1415). 著者等はクロルデンの in vitroの毒性実験によ るラット肝ミトコンドリアの酸化的リン酸化反 応に对する阻害作用の報告 ${ }^{(6)}$ を行ってきた。今 回，更にクロルデンの肝毒性についてラット肝 ミトコンドリア (Mt) を用いて各呼吸基質での 呼吸活性に及はす影響, 特に電子伝達系に与之 る影響について検討したので報告する。

\section{材料と方法}

1. 肝ミトコンドリア $(\mathrm{Mt})$ の分離

体重約200 gのドンリュウ柔ラット(雄)より Hogeboom, Schneider 法 ${ }^{17}$ の内海による変法 ${ }^{18}$ により肝 Mtを分画し， $0.25 \mathrm{M}$ sucrose, $4 \mathrm{mM}$ Tris- $\mathrm{HCl}$ buffer（pH7.4）に懸濁し実験に供し た. Mt 蛋白の定量は, 牛血清アルブミンを標準

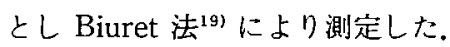

2.ミトコンドリア呼吸活性の測定 $0.15 \mathrm{M} \mathrm{KCl}, 10 \mathrm{mM}$ Tris- $\mathrm{HCl}$ buffer (pH7.4), $5 \mathrm{mM} \mathrm{MgCl}_{2}, 10 \mathrm{mM}$ phosphate buffer $(\mathrm{pH} 7.4) よ り$ 成る反応液に $\mathrm{Mt}(2.4 \mathrm{mg}$ of protein $/ \mathrm{ml}$ ) 縣濁し， $25^{\circ} \mathrm{C}$ で賢找しながら 呼吸基質 $5 \mathrm{mM}$ succinate (suc), $5 \mathrm{mM} \beta$ -

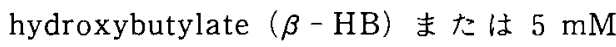
ascorbate $+0.1 \mathrm{mM} N, \mathrm{~N}, \mathrm{~N}^{\prime}, \mathrm{N}^{\prime}$ tetramethyl phenylene-diamine(TMPD), chlordane, 0.3 $\mathrm{mM} \mathrm{ADP}$ を順次添加して全量を $3.5 \mathrm{ml}$ とし, 溶存酸素濃度の変化をガルバ二一型酸素電極(給 水化学）を用いて, 連続的に記録測定した ${ }^{20)}$.

3. 呼吸開放時のクロルデンの影響の測定

$0.15 \mathrm{M} \mathrm{KCl}, 10 \mathrm{mM}$ Tris- $\mathrm{HCl}$ buffer (pH7.4), $5 \mathrm{mM} \mathrm{MgCl}_{2}, 10 \mathrm{mM}$ phosphate buffer（pH7.4）より成る反応液に Mt（1.6mg of protein $/ \mathrm{ml}$ ), 呼吸基質として $5 \mathrm{mM}$ suc, 5 $\mathrm{mM} \beta-\mathrm{HB}$ または $5 \mathrm{mM}$ asc $+\mathrm{TMPD}$ をづに $0.02 \mathrm{mM} \mathrm{DNP}$ を加えて呼吸を開放し, 各 chlordane を添加して溶存酸素の変化を測定した。 


\section{4．超音波処理要ミトコンドリア粒子の調整}

Mt 懸濁液を氷冷しながら， 2 分間 Sonifire (Bronson)により超音波処理し未粉研の沈測を 除き $30000 \mathrm{rpm}$ で10分間遠心後，実験に供した。 $\mathrm{NADH}$-cytochrome $\mathrm{C}$ reductase は反応液 0.15 $\mathrm{M} \mathrm{KCl}, 5 \mathrm{mM} \mathrm{MgCl}, 10 \mathrm{mM}$ Tris- $\mathrm{HCl}$ buffer (pH7.4)，0.02mM cytochrome C 中で heptachlor 添加後 3 分間 incubation $L, 0.1 \mathrm{mM}$ $\mathrm{NADH}$ を基質として550nm での cytochrome $\mathrm{C} の$ 還元を日立ダブルビーム分光光度計を用い て測定した. NADH-DCIP reductase は, dichloroindophenol (DCIP) の還元を600nm で測定 した.

\section{5 . 試薬}

trans-chlordane, cis-chlordane, heptachlor は和光純薬の製品を用い, ethanol に溶解して実 験に供した.ADP, NADH, cytochrome C(type III) は Sigma 社の製品を，他の試薬はすべて特 級品を用いた。

\section{結果}

1. 呼吸基質別のクロルデン主成分の影響

Table 1 は $5 \mathrm{mM} \quad \beta$-hydroxybutylate, 5 $\mathrm{mM}$ succinate あるいは $5 \mathrm{mM}$ ascobate+ TMPDをそれぞれ呼吸基質に用いた時, $50 \mu \mathrm{M}$ trans-chlordane, cis-chlordane 及び heptachlor を添加した際の呼吸への影響を示したもので ある、数值は control に対する\%である. Table 1から明らかなよに，呼吸基質が ascorbate の場合は state 3 呼吸, state 4 呼吸に影響を 与えなかった. $\beta$-hydroxybutylate の場合は state 3 呼吸をやや抑制したが state 4 呼吸に おいては変化がみられなかった. succinate を呼 吸基質とした場合は， state 3 呼吸， state 4 呼 吸の両者を抑制した。特に state 3 呼吸の抑制 がより強く見られた. 各 chlordane 間の作用の 比較では trans-chlordane が cis-chlordane と heptachlor に比べ強かった.

2. 呼吸開放時おける各呼吸基質とクロルデン 主成分との関係。

呼吸基質として $\beta$-hydroxybutylate, succinate, ascorbate 用い, DNP で呼吸を開放 し 1 分每に trans-chlordane, cis-chlordane, heptachlor をそれぞれ50 $\mu \mathrm{M}$ 添加して溶存酸素 の消費速度を測定した，Table 2 はそれらの值 を controlに対する\%として各 chlordane 間で まとめたものである。この表から明らかなよう に，ascorbate を呼吸基質に用いた場合には， 各 chlordane ともこの濃度では溶存酸素消費の 抑制作用は認められなかった。 $\beta$-hydrox-

Table 1 Effect of chlordane-components on mitochondrial respiration

\begin{tabular}{|c|c|c|c|c|c|c|}
\hline \multirow{2}{*}{ experiment } & \multicolumn{2}{|c|}{$\beta$-hydroxybutylate } & \multicolumn{2}{|c|}{ succinate } & \multicolumn{2}{|c|}{ ascorbate } \\
\hline & state 3 & state 4 & state 3 & state 4 & state 3 & state 4 \\
\hline trans-chlordane & 80 & 108 & 37 & 72 & 100 & 100 \\
\hline cis-chlordane & 89 & 100 & 45 & 70 & 100 & 100 \\
\hline heptachlor & 95 & 100 & 47 & 70 & 100 & 100 \\
\hline
\end{tabular}

Values are expressed as percents of control

Table 2 Effect of chlordane-components on DNP-released respiration

\begin{tabular}{|c|c|c|c|c|c|c|}
\hline \multirow{2}{*}{ substrate } & \multicolumn{2}{|c|}{ trans-chlordane } & \multicolumn{2}{|c|}{ cis-chlordane } & \multicolumn{2}{|c|}{ heptachlor } \\
\hline & $50 \mu \mathrm{M}$ & $100 \mu \mathrm{M}$ & $50 \mu \mathrm{M}$ & $100 \mu \mathrm{M}$ & $50 \mu \mathrm{M}$ & $100 \mu \mathrm{M}$ \\
\hline$\beta$-hydroxybutylate & 100 & 94 & 100 & 98 & 100 & 98 \\
\hline succinate & 45 & 33 & 46 & 41 & 45 & 42 \\
\hline ascorbate & 100 & 100 & 100 & 100 & 100 & 100 \\
\hline
\end{tabular}

Values are expressed as percents of control 
ybutylate を呼吸基質に用いた場合では，各 chlordane ともわずかな抑制傾向がみられた。

Succinate を呼吸基質に用いた場合は，濃度 依存的に各 chlordane とも強く抑制し，その作 用強度は酸化的リン酸化反応阻害と同じように trans-chlordane $か ゙$ cis-chlordane $と$ heptachlor に比べ強くあらわれた.

3. Fig. 1 は heptachlor の電子伝達系への作 用を $\mathrm{NADH}$ を基質に用いて亜 $\mathrm{Mt}$ 粒子での cytochrome C, DCIP の還元への影響を調べた ものである、本図に示されるように $100 \mu \mathrm{M}$ 濃 度 heptachlor では NADHによる cytochrome C, DCIPの還元作用を方ずかに抑制する傾向が 見られた。

\section{考察}

生体内でエネルギ一転換作用を行う Mtにつ いては，多くの化学物質による阻害が知られて いる.Mtの酸化的リン酸化反応に対する阻害様 式は電子伝達阻害, 脱共役およびエネルギ一転 換阻害に大別されるが，その区分は必ずしも容 易でない. 本実験に用いた trans-chlordane, cis -chlordane, heptachlorの Mtにおよばす影響 について succinate を呼吸基質にした場合，比 較的低濃度で state 3 呼吸および state 4 呼吸 を抑制させるが，特に state 3 呼吸の低下が著 しかった. 緒方らの分類 ${ }^{21)}$ によれば, chlordane は電子伝達阻害のグループに分類される。この ことは, trans-chlordane の低濃度では抑制され た state 3 呼吸が DNP で解放されるが，500 $\mu \mathrm{M}$ で抑制された呼吸は DNPで解放されず呼 吸阻害作用があることからも推測される ${ }^{16)}$. trans -chlordane, cis-chlordane, heptachlor 間での 作用強度はすでに報告されているが16)，これら実 験結果からも同じ傾向が観察された。

酸化的リン酸化反応での呼吸基質の違いによ る chlordane 主成分の作用の差について succinate, $\beta$-hydroxybutylate, ascorbate $を$ 用い て検討した結果, succinateの場合に抑制が著し かった. $\beta$-hydroxybutylate の場合は state 3 呼吸を僅かに抑制し state 4 呼吸には影響がみ られなかった，さらに，ascorbate の場合には state 3 呼吸, state 4 呼吸どちらにも影響がみ

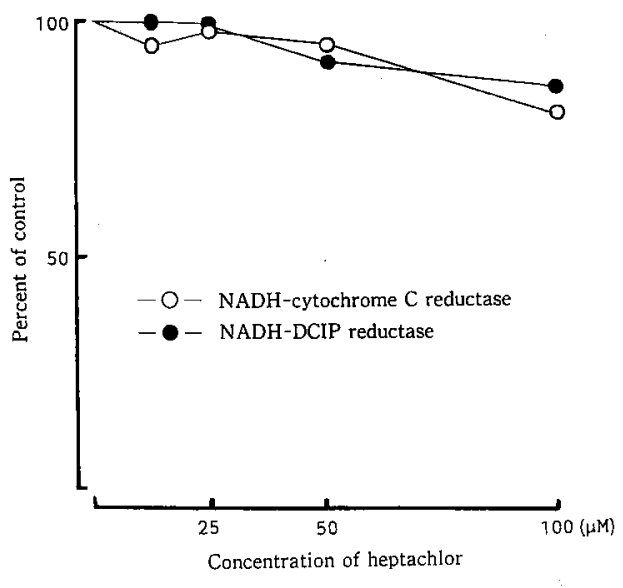

Fig. I Effect of heptachlor on the reduction of cytochrome $\mathrm{C}$ and dichloroindophenol added to $\mathrm{NADH}$ of submitochondrial particles

られなかった． DNP で呼吸解放された Mt の chlordaneによる抑制は，呼吸基質 succinate $の$ 場合が著しいが呼吸基質 $\beta$-hydroxybutylate で も抑制が観察される。これらの結果より，この 実験に使用した chlordane は site 特異的な電 子伝達阻害剂ロテノン,アンチマイシン $\mathrm{A}, \mathrm{KCN}$ のような作用ではないと考えられる。更に, 100 $\mu \mathrm{M}$ heptachlor は亜ミトコンドリア粒子での NADH による cytochrome C, DCIP 還元作用 を僅かに抑制することから $\beta$-hydroxybutylate での抑制と一致する.以上の結果から chlordane は Mtの呼吸鎖の site IIを強く抑制するが site Iにも影響をあたえることが推測される。

\section{結論}

Chlordane の主成分である trans-chlordane, cis-chlordane, heptachlor についてラット肝ミ トコンドリアに对する影響を調べ以下の成績を 得た.

1. 酸化的リン酸化反応への影響：transchlordane, cis-chlordane, heptachlor は succinate を呼吸基質にした場合には, state 3 呼 吸とstate 4 呼吸を抑制した。またこれらの chlordane 化合物は, $\beta$-hydroxybutylate 吸基質にしたばあいでは，わずかに state 3 呼 
吸を抑制したが, ascorbateのばあいでは state 3 呼吸, state 4 呼吸の抑制が認められなかった。 これらの chlordane 化合物間では, trans-chlordane が cis-chlordane, heptachlor に比べ強い 抑制作用を示す傾向がみられた。

2. DNP 解放呼吸への影響: trans-chlordane, cis-chlordane, heptachlor は succinate での解放呼吸を強く抑制した。これらの chlordane 化合物は, $\beta$-hydroxybutylate $の$ 呼吸を わずかに抑制したが, ascorbate の呼吸では抑 制は認められなかった。これらの chlordane 化
合物間では, trans-chlordane が cis-chlordane, heptachlorに比べ強い抑制作用を示す傾向がみ られた。

3．亜ミトコンドリア粒子への影響： heptachlor は NADH による cytochrome C, DCIPの 還元をわずかに抑制する傾向がみられた。

本稿を終えるにあたり，御想篤なる御指導，御校 閲を賜った岡山大学医学部緒方正名教授に深甚の謝 意を表します。

\section{文}

献

1) 環境庁環境保健部保健調查室編：化学物質と環境。東京、環境庁環境保健部保健調查室 (1983) pp 8-71.

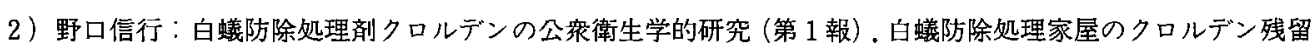
と作業者の血液検查成績について. 岡山医誌（1985）97，315-326.

3) Saito I, Kawamura N, Uno K, Hisanaga N, Takeuchi Y, Ono Y, Iwata M, Gotoh M, Okutani H, Matsumoto I, Fukaya Y, Yoshitomi S and Ohno Y : Relationship between chlordane and its metabolites in blood of pest control operators and spraying conditions. Int Arch Occup Environ Health (1986) 58, 91-97.

4）宮崎奉之, 山下達典，松本昌雄：海水，河川水及び魚介類中の残留クロルデン類の成分パターン．食衛誌 (1986) 27, 49-58.

5) Oloffs PC, Albright LJ and Sgeto SY : Persistence of residues in water and sediment of a freashwater lake after surface application of technical chlordane. J Environ Sci Health (1978) B13, 4758.

6) 宮崎奉之, 秋山和幸, 金子誠二, 堀井昭三,山岸達典, 村 上ー：魚介類中のクロルデンとその近緑化合物 の分離同定と定量法。東京衛研年報（1980）31，161-165.

7) Eugene EK : Correlation of bioconcetration factors of chemicals in aquatic and terrestrial organisms with thier physical propaties. Environ Sci Technol (1980) 14, 553-556.

8) Mjyazaki $T$, Akiyama $K$, Kaneko $S$, Horii $S$ and Yamagishi $T$ : Chlordane residues in human milk. Bull Environ Contam Toxicol (1980) 25, 518-523.

9) Tojo $Y$, Wariishi $M$, Suzuki $Y$ and Nishiyama $\mathrm{K}$ : Quantitation of chlordane residues in mothers' milk. Arch Environ Contam Toxicol (1986) 15, 327-332.

10）野口信行：白䗒防除処理剂クロルデンの公采衛生学的研究(第 2 報).クロルデン暴露ラットの生体内運命に ついて. 岡山医誌 (1985) 97，327-339.

11) Boyd EM and Taylor FI : The accute oral toxicity of chlordane in albino rats fed for 28 days from weaning on a protein deficient diet. Ind Med Surg (1969) 38, 434-441.

12) Deichman WB and Peplinger ML : Effect of combinations of pesticide on reproduction of mice. Abstract of Papers for the fifth Annual Meeting of the Society of Toxicology. Williamsberg, Virginia, March 14-16, 1966. Toxicol Appl Pharmacol (1966) 8, 337-338.

13) Epstein SS : Carcinogenicity of heptachlor and chlordane. Sci Total Environ (1976) 6, 103-154.

14）森孝昭：塩化ベンゼンの生体膜に对する作用. 第林報. 生体内投与における0-ジクロルベンゼンのラッ 
卜肝に対する作用．岡山医誌（1982）94，967-972.

15）池上幸江，土橋文江，大野光宣，西出英一：ラット肝䁍及び血清脂質成分に対する芳香族塩素化合物の影響 と化学構造の関係。食衛誌 (1987) 28, 436-444.

16) Ogata M, Izushi F, Eto $K$, Sakai R, Inoue B and Noguchi N : Effect of chlordane on hepatic mitochondrial respiration. Toxicol Lett (1989) 48, 67-74.

17) Hogeboom GH, Schneider WC and Pallade GC : Cytochemical studies of mammalian tissues. I. Isolation of intact mitochondria from rat liver ; some biochemical properties of mitochondria and submicroscopic particulate material. J Biol Chem (1948) 172, 619-635.

18) Utsumi $\mathrm{K}$ : Relation between mitochondria swelling induced by inorganic phosphate and accumulation of $\mathrm{P}^{32}$ in mitochondrial Pi fraction. Acta Med Okayama (1963) 17, 258-271.

19) Gornall AG, Bardawill CJ and David MM : Determination of serum proteins by the biuret reaction. J Biol Chem (1949) 177, 751-766.

20) Hagihara B : Technique for the application of polarography to mitochondrial respiration. Biochim Biophys Acta (1961) 46, 134-142.

21) Ogata M, Mori T, Izushi F, Etoh $K$, Sakai R, Meguro $T$ and Inoue $B$ : Classification of potentially toxic chemicals based on their effects on mitochondrial respiration. Physiol Chem Phys Med NMR (1983) 15, 229-232. 


\title{
Effect of chlordane on rat liver mitochondrial respiration
}

\section{Fumio Izushi}

Department of Public Health,

\author{
Okayama University Medical School,
}

Okayama 700, Japan

(Director : Prof. M. Ogata)

In attempting to clarify the toxicity of chlordane, its effects on respiratory activities in hepatic mitochondria and on electron transport in sonicated submitochondrial particles were examined.

State 3 and 4 respiration, and DNP-released respiration were inhibited by chlordane compounds, with the ranked degree of inhibition was in descending order being, transchlordane, cis-chlordane, and heptachlor. The inhibitory effects of chlordane were more remarkable in the presence of succinate as a respiratory substrate than in the presence of $\beta$-hydroxybutylate or ascorbate. Heptachlor also decreased cytochrome $\mathrm{C}$ reduction by NADH-cytochrome $C$ reductase. The results suggest that chlordane does not seem to be a specific inhibitor such as cyanide, rotenone, or antimycin $A$. 